\title{
Cinema, Popular Entertainment, Literature, and Television
}

\author{
Sally Faulkner, Vicente Sánchez-Biosca, \\ and Paul Julian Smith
}

\section{Cinema and Other Forms of Entertainment Prior to the Arrival of Television (Vicente Sánchez-Biosca)}

In an excellent methodological essay, Rick Altman (1996) has argued that the notion that cinema has a stable identity across time is, at best, an illusion. Specifically, its identity has become diffuse at moments when it has entered into circuits of transformative exchange and competition with other forms of leisure activity. Altman focused on the age of the nickelodeon (exhibition at fairgrounds or amusement parks, early cinema theaters) and on the sound revolution (producing forms such as "radio with images" and filmed theater), proposing a "crisis model" of historiography in which what we call cinema includes heterogeneous, unstable scenarios that have emerged at crisis points in its history.

Spanish cinema - like cinema elsewhere - has existed within a relational economy of leisure, entertainment, and representation that makes it difficult to consider it as a separate entity. Research is still needed into the relationship of cinema to the broad range of cultural and entertainment practices with which it forms a continuum, and into the ways in which this relationship has changed at certain critical junctures; in Spain such research has not been attempted to date. Such a study would have to consider cinema-going in relation to the full range of leisure activities available in any given period: the forms of entertainment open to different social classes; family circles and their domestic economy, which made certain cultural practices accessible to some of their members rather than others; and the social, sexual, or gender constituencies for particular forms of cultural consumption. Who goes to see what with whom may depend on the day of the week; for example, 
the whole family might go to the cinema on Sundays, the males to a cabaret on Saturdays (with a female partner or other males), the mother and children to the neighborhood cinema on Thursdays (the maid's day off), the adults maybe to a corrida in the bullfighting season, or the males to a football match on Sundays. Sometimes these cultural options might clash; for example, if their days of the week coincided (in the examples above, the family outing to the cinema and the football match), or if they appealed to incompatible social sectors. In other, more complex instances they might overlap, exchanging attributes or imitating each other: actresses who combined theater with music hall, bullfighters recruited to act in bullfighting films, folkloric stage singers discovered by film producers (as Lola Flores was by Cesáreo González), or footballers from the other side of the Iron Curtain who became stars of anticommunist movies (such as the Hungarian Ladislao Kubala in Los ases buscan la paz / Aces in Search of Peace (Arturo Ruiz-Castillo, 1955)).

Sport (especially football, which the Franco regime turned into the mass sport par excellence); theater (particularly the popular sainete (one-act low-life farce), the musical revue, and zarzuela (popular operetta)); radio; and bullfighting all shared a leisure economy with cinema prior to the arrival of television. Based in the homeafter the early 1960s when Manuel Fraga Iribarne, as Minister of Information and Tourism, encouraged teleclubes (television clubs) - television followed a strategy of absorption of other cultural forms, rather than entering into conflict with them. Accordingly, it gradually came to accommodate most forms of entertainment that required a venue, an audience, and specific material conditions; this substantially modified the previous cultural dynamic. Nonetheless, the lateness of the small screen's implantation in Spain (one cannot talk of the medium's social penetration until the mid-1960s) leaves an extended period in the history of cinema to be analyzed in terms of comparative leisure consumption.

This section can only make an initial attempt at exploration of this field; it will do so by focusing on two symptomatic case studies. The first is a concrete but highly revealing event: the Exposición Regional y Nacional (Regional and National Exhibition) held in Valencia in 1909 and 1910. Its organization shows the liminal position of cinema and its uncertain status in a city whose economic and political leaders had opted for modernization. The second will discuss the relationship to cinema of the cuplé (a narrative song form popularized by cabaret; see Chapter 7), which in turn is connected with the history of song and of the musical revue indeed, all of these terms are conceptually and historically polyvalent. The premise will be that these cultural formulas or scenarios exist both inside and outside cinema, and that the case of the cuplé is a story of absences, ellipses, come-backs, and areas of overlap. Other phenomena that could fruitfully have been studied are (among others) the bullfighting film genre, which rewrites the silver screen's star system, or football, which gave rise to an idiosyncratic rhetoric - for example, Matías Prats, as football commentator for the NO-DO newsreels (see Chapter 18), shaped a specific language or jargon from which audiovisual sports journalism would not free itself for decades. 


\section{A Strange Attraction}

In 1909, the city of Valencia was turned upside down by an initiative aimed at plunging it into modernity, in its industrial, urban, touristic, and leisure facets. The Ateneo Mercantil (Chamber of Commerce), headed by Tomás Trénor, mounted a Regional Exhibition that the following year would be renamed "National Exhibition." February 13, 1909 saw the publication of the terms of exploitation of the Cinematógrafo y Parque de Atracciones (Cinema and Amusement Park) (PingarrónEsaín 2009), showing that the two things were seen as a unit, both in the minds of a committee whose members were educated businessmen and in the social imaginary of the period that made it a success. The physical context for the cinema was, then, the glissoire roulant aka tobogán (helter skelter), the globo mariposa (hot-air balloon, literally "butterfly balloon"), the tapis volant (flying carpet), the mechanical staircase, the roller coaster, and other funfair attractions. This regional exhibition supposed access to technological modernity (inventions, stunts, fascination with the latest mechanical devices) but also a new experience of time and spatial vertigo that were constants of the World Fairs of the nineteenth century, especially those of Paris, as lucidly analyzed by Walter Benjamin (1982). Moreover, the cinema was located in the first purpose-built, solid-structure building to be constructed in the city of Valencia expressly for the screening of films. The exhibition coincided, then, with a key moment in the history of cinema in which it was starting to be housed in spaces designed for that purpose and, at the same time, itinerant cinema was starting to become a thing of the past. The success of the film screenings at the exhibition led to their move to another venue in the grounds, the Teatro-Circo (solid-structure circus venue), with additional open-air sessions at the Fuente Luminosa (Illuminated Fountain), taking advantage of the temperate Mediterranean climate.

Thus, cinema was - in terms of how it was perceived socially and as a form of entertainment, both of which have technical and formal consequences - a space of the imagination related to the surrounding attractions, the circus, the outdoor location, and strong perceptual and emotional experiences. In addition to the initial lack of a fixed or even specifically designated space for the film screenings, no one - whether in the press of the time or in the memoirs of those responsible for the venture - mentioned the actual content of the films projected. What made it a success was the spectacle as such. This tells us what cinema represented to the public imaginary in a privileged enclave in Spain in 1909 and 1910: a multifaceted instrument, unrelated to and distanced from art, paradoxically since its creators for example, the Valencian photographer and cinema pioneer Ángel García Cardona (see Chapter 12) - were cameramen with a gift for composition and a skilled technical eye. But what triumphed was the idea of leisure, of the technical gimmick, internally geared to the production of sensational (rather than artistic) effects, and externally merging with other attractions on a grander scale (Gunning 1986). In its spectacularity and sensationalism, Spanish cinema of 1909 would be 
incomprehensible if viewed solely as cinema. It should be added that, at the time, Valencia was the home of the Cuesta production company, which would be decisive in giving shape to early cinema in Spain (Lahoz 2010).

\section{Those Times of the Cuplé}

In 1958, José Luis Merino made Aquellos tiempos del cuplé / Those Times of the "Cuple" - a nostalgic film that recreates, with excessive concessions to public decorum, the period when this particular entertainment form, originating in France (its name derives from the French couplet), triumphed in Spain (see "The Heyday of the Musical Film" in Chapter 6 and "The 1920s and 1930s" in Chapter 7). The film's star, Lilian de Celis, came from the same cabaret tradition depicted in the film. This was the time of El último cuplé / The Last Torch Song (Juan de Orduña, 1957), starring Sara Montiel, which starts in Barcelona in the 1950s, as a former singing star, who had left the stage for love, makes a come-back. A flashback takes us back three decades to when Barcelona's Paralelo (the city's entertainment district) was at its height, and transports us to Paris, the cradle of the genre and of variety theater and the revue.

The cuple dominated the Spanish stage from the start of the twentieth century, acting as a popular counterpoint to sophisticated operatic performance. Drawing on certain stage traditions and popular song, and replacing the late-nineteenthcentury vogue for the zarzuela and género chico (one-act musical play), it continued the tradition of the revue that had originated in the 1860s. The most striking feature of the cuple is that, during the first decade of the twentieth century, it was characterized by what at the time was called sicalipsis, which Serge Salaün (1990) defines as a "perversion del género chico en género ínfimo, mediante el erotismo" (degradation of the género chico [light genre] to the género infimo [lightest genre; a term then used for saucy stage acts], thanks to its eroticism). This "naughty" slant was exemplified in the so-called canción de doble intención (song based on double entendre), the sexual innuendo of its lyrics, or the mismatch between innocent lyrics and the erotic gestuality of the female performer - as in the famous song " $\mathrm{La}$ pulga" (The Flea) - but also in the moderate or heavy sexual license surrounding its venues and stars, and the love lives of the latter. This, however, is not what passed into cinema, if we look at the films of the internationally famous cupletista Raquel Meller, whose films included Los arlequines de seda y oro / Silk and Gold Harlequins (Ricardo de Baños, 1919) and Violetas imperiales / Imperial Violets (Henry Roussell, 1923) and who would immortalize the songs "La violetera" (The Violet Seller) and "El relicario" (The Reliquary). Not surprisingly, the cuplé disappeared from cinema altogether during the first decades of the Franco dictatorship because of its associations with a tawdry sexual underworld (though a degree of sexual innuendo was tolerated in select venues). It was Sara Montiel who would, around 1960, be responsible, almost single-handedly, for bringing back this female 
prototype; despite the sanitization perceptible in these revivals, the relation of the cuplé to sexual license was made clear. If El último cuplé meant a revival of the genre (Montiel 2000: 236), Montiel's subsequent films - Pecado de amor / Sin of Love (Luis César Amadori, 1961), La bella Lola (Alfonso Balcázar, 1962), La reina del Chantecler / Queen of the Chantecler (Rafael Gil, 1962), La dama de Beirut / The Woman from Beirut (Ladislao Vajda, 1965), and Tuset Street (Jorge Grau and Luis Marquina, 1968) would continue in the same vein with great success.

The earlier ellipsis of several decades during which cinema avoided the cuplé, although it had continued as live performance under a cloak of discretion if not semi-clandestinity, had been filled with the costumes and narrative plotlines - and explosion on the radio and in the record industry - of another kind of song: that of the chaste folkloric female star, the performer of Andalusian song and the traditional copla, morally puritanical and anatomically much more decorous, embodied successfully by Imperio Argentina, Estrellita Castro, Lola Flores, Paquita Rico, Gracia de Triana, and Marifé de Triana, even though their private lives (sometimes aired in public) did not correspond to the moral norms of the day. It is curious to note that a figure like Carmen Sevilla would in the 1960s opt for an extraordinary mix of the folkloric and the permissive, which went down well with French audiences - a kind of flamenca lite, as Terenci Moix called her (1993). But that would take us into another period.

\section{Literary Adaptations (Sally Faulkner)}

Literary adaptations - just one of many possible connections between film and literature - have been central to the history of cinema, popular with practitioners and audiences from the silent era to the present, and have ranged across genres as varied as costume drama, film noir, and youth movies. As Linda Hutcheon notes, most Best Picture awards at the Oscars, which are selected by industry professionals, have gone to films based on literary works (2006: 4). Yet critics remain divided, raising concerns about "purity" or, conversely, stressing originality.

The case of Spain is no exception. If one were to write the history of Spanish cinema referring only to literary adaptations, virtually no period, genre, political orientation, or degree of success would be left out. As in other countries, literary adaptations of classic texts played a key role in the early constitution of film as the seventh art - for instance, via versions of Cervantes' Don Quijote (first adapted by Narciso Cuyàs in 1908) and Calderón's plays (as in Adrià Gual's 1914 version of El alcalde de Zalamea / The Mayor of Zalamea). Following José Buchs' popular 1921 La verbena de la Paloma / Festival of the Virgin of the Dove, adaptations of zarzuelas dominated Spanish cinema of the early 1920s, constituting over half of films produced in 1923 (Pérez Perucha 1995: 90). Notwithstanding later successes (Benito Perojo made a sound version of La verbena in 1935), 1925 saw the beginning of an alternative vogue 
for adaptations of novels (Alejandro Pérez Lugín successfully filmed his novels La casa de la Troya / College Boarding House and Currito de la Cruz / Currito of the Cross that year) that has continued to the present (Sánchez Salas 2007: 408).

Under the Franco dictatorship, literary adaptations became politicized. Critics have questioned the frequent suppostion that the cinema of early Francoism uniformly promoted regime ideology, and this holds true for adaptations of the period. For instance, while Antonio Román's version of Lope de Vega's Fuenteovejuna (1947) used Spain's literary Golden Age (sixteenth and seventeenth centuries) as a mirror for Francoist values, Peter Evans notes that the star Amparo Rivelles disrupts its promotion of a conservative gender ideology (1997: 5-6). In other cases, adaptations allowed directors to smuggle sexually racy plots past the censors - for example, via Alarcón in El escándalo / The Scandal (José Luis Sáenz de Heredia, 1943) and Palacio Valdés in La fe / The Faith (Rafael Gil, 1947) (Labanyi 1995: 7-8). Adaptations of antiauthoritarian writers that got past the censors implicitly critized the regime by displaying social injustice (Perojo's 1940 version of Galdós' Marianela) or what Jo Labanyi (1995) terms the "family in crisis" (Carlos Serrano de Osma’s 1946 adaptation of Unamuno’s Abel Sánchez).

This potential for creative adaptation to function as a political act of dissent was consolidated in the late dictatorship and transition periods. For example, Miguel Picazo used the early-twentieth-century writer and philosopher Miguel de Unamuno to condemn the stifling patriarchal restrictions of 1960s provincial Spain (aided by the performance of Aurora Bautista) in La tía Tula / Aunt Tula (1964) (Faulkner 2006: 101-24). The first case study below examines how Pedro Olea effected a similar critique via the nineteenth-century realist novelist Benito Pérez Galdós in Tormento / Torment (1974). In the early post-Franco years, despite the fact that many films were based on nineteenth- and early-to-mid-twentieth-century originals, literary adaptations in Spanish cinema and television alike articulated the values of a new democratic Spain. Thus, in La colmena / The Beehive (1982), Mario Camus turned to Camilo José Cela's nihilistic novel of 1951, originally banned by the Francoist censorship, to enunciate antiauthoritarian values in the present (Faulkner 2004: 24-33). This film's combination of a complex work by a major author with popular actors and high production values indicated a successful middlebrow trend. Manuel Palacio (2001: 153) has traced a similar didactic drive to promote democratic values through literary classics in television adaptations of the transition period - for example, via Galdós again in Camus' ten-part Fortunata y Jacinta / Fortunata and Jacinta (1980). No longer enjoying the state subsidies available to literary adaptations in the 1980s - under both UCD (centre-right) and PSOE (socialist) governments - directors in the 1990s and beyond have nonetheless continued successfully, if occasionally, to connect with audiences through adaptations, on both large and small screens; for example, Pilar Miró's film version of Lope de Vega's El perro del hortelano / The Dog in the Manger (1996), discussed as the second case study below, and Fernando Méndez Leite's three-part television production of Leopoldo Alas' 1885-6 novel La Regenta (1995). 


\section{Adaptation Theory}

Following the first book on the subject, by George Bluestone in 1957, early adaptation studies focused principally on the question of fidelity. This approach had the merit of dealing with the material differences between the written medium of literature and the audiovisual medium of film, asking, for example, how character might be created through descriptive passages in a novel or dialogue and stage directions in a play, versus casting, performance style, screenplay, mise-en-scène, cinematography, editing, and sound in film. However, whether because too many studies judged film "worse" or because the authors were often literary rather than film scholars, "fidelity criticism" - first condemned by Andrew Horton and Joan Magretta in 1981 - became the straw man of adaptation studies. Whatever adaptation theory was, critics protested from the 1980s onward, it was not "fidelity criticism." While it can be argued that subjective judgments about "fidelity" to some elusive "essence" of a literary text have no place in adaptation theory today, much is lost if we dismiss fidelity completely. Linda Hutcheon argues that, whatever an adapter aims to do, it is rarely to be faithful (2006: xiii). Surely this is counterintuitive. If there is no desire to conjure up the literary text, albeit it in an entirely different form, why bother to adapt at all? A key risk in dismissing "fidelity" is that we lose the important work of close textual analysis of the two media. Dismissing "fidelity" also means dismissing audience response, since that tends to be the key issue for spectators familiar with the source text. While the case studies below address audience reception through critics' reviews in the press and box-office statistics, both available to scholars, a fruitful direction for further enquiry might be reintroduction of the issue of fidelity through audience research in cases where access to viewers is feasible.

The avoidance of audience response that resulted from the rejection of "fidelity criticism" was continued by the belated turn to structuralism by adaptation critics in the 1990s (e.g., McFarlane 1996). Structuralist critics dissected films and their sources in terms of narrative codes, permitting what they claimed were "objective" conclusions about the extent to which an adaptation duplicated or departed from its source, as an antidote to what they saw as the reliance on "subjective" opinions in "fidelity criticism." Also lost in this structuralist turn was the crucial question of context: that is, consideration of the commercial, cultural, and political reasons why certain texts are adapted at certain times, and of how adaptations are shaped by changing institutional, social, and political environments.

Since the start of the twenty-first century, adaptation studies has transformed itself by energetically, if belatedly, embracing poststructuralist theory - for example, Derridean deconstruction, the Lacanian questioning of the unified subject, and the Foucauldian rethinking of the author (Stam 2005) - as well as cultural studies. In 1999, Deborah Cartmell and Imelda Whelehan identified the largely cultural issues of "history, nostalgia, ideology" and "audience, pleasure and intertextuality” (1999: 11, 15) as key concerns of the field. In 2000, James Naremore 
reprinted articles by André Bazin (originally 1948) and Dudley Andrew (originally 1984), which adaptation critics had missed in their embrace of structuralism. By rejecting both the subjective hierarchy of "better/worse" inherent in "fidelity criticism" and the avoidance of context that limits structuralist methodology, these two articles point to a cultural studies approach avant la lettre (Naremore 2000: 1). Today adaptation studies is attracting the attention of major film, cultural, and literary scholars (Vincendeau 2001; Hutcheon 2006; Sanders 2006), and 2008 saw the launch of the specialist academic journal Adaptation.

Scholarship on literary adaptations within Spanish film studies has followed this same trajectory, with structuralism dominant in the 1990s and with recent critics in the United Kingdom and Spain exploring cultural issues (Sánchez Salas 2002, 2007; Faulkner 2004; Pérez Bowie 2004). By considering two films from different decades - the 1970s and the 1990s - the two case studies offered here stress the importance of taking cultural context into account. The aim is to explore how adaptation can serve political and gender critique. This will be analyzed through attention to casting, performance style, and film form in the genres of melodrama and romantic comedy.

\section{Tormento / Torment (Pedro Olea, 1974)}

Spanish cinema of the early 1970s saw a mini-boom of classic literary adaptations. The catalyst was Luis Buñuel's 1970 Tristana - also based on a novel by Galdós which was passed by the censors with only minor objections (Sánchez Salas 2002: 201) and, according to the Ministry of Culture database (www.mcu.es/ cine/index. html), attracted nearly two million viewers and made over four hundred thousand euros. Producers, mired in one of Spanish cinema's perennial financial crises, saw the commercial possibilities here; the ensuing copycat adaptations of a wide range of literary texts were producer-led. A new university-educated, relatively wealthy, and predominantly urban audience was the target for this middlebrow fare; the graduates of the Escuela Oficial de Cine (EOC; Official Film School), for whom government subsidies had dried up, were its ideal directors. Thus, the producer José Frade commissioned Olea to direct a film version of Galdós' 1884 novel Tormento.

The only kind of audience response available for this film - press reviews - cannot be taken to be indicative of public opinion since the press was censored. The film was released a year before Franco's death; there was a return to hard-line censorship in the last two years of his rule. Reviews sampled at Filmoteca Española show that hostile reviewers used the stock fidelity argument to pass moral judgment on the film. Olea's change to the ending, which explicitly verbalizes both Rosalía's annoyance and Agustín's extramarital arrangement, was a particular source of outrage to critics in the pro-regime press (Arroita Jauregui 1974, writing in Arriba; Ramos 1974, writing in El Alcázar). In a more progressive review, the fidelity issue was also raised but as a smokescreen to critique the current situation 
in Spain (López Sancho 1974, writing in the conservative but more open-minded $A B C)$. Today, we can make explicit what was implicit here: Galdós' social critique serves as a "scalpel" (the word used by the $A B C$ reviewer) for Olea to dissect the dying days of Francoism. The censors fixated on the plot's potential sensationalism - a priest's love affair - requiring the script to be revised three times before filming could proceed (Navarrete 2003: 134). But the film's critique lies not in its anticlericalism (from the 1960s onward, progressive elements of the clergy had opposed the regime) but in its portrayal of the hollow values of the bourgeoisie and the disruptive presence of strong female characters. These two points of critique struck at the ideological core of late Francoism, the economic policies of which, from the 1959 Stabilization Plan onward, had focused on consolidating the middle classes, unleashing social mobility while continuing to protect patriarchy. The film's critique of Francoist values was reinforced by the fact that the author of its source text was the "liberal crusader" Galdós (Berkowitz 1948), whose work had been blacklisted in the ideologically stricter years of early Francoism (Faulkner 2004: 90). The tentative nature of the film's critique is in line with the tentative approach to political change that would follow Franco's death the following year; it is appropriately set in the late-nineteenth-century Restoration period (named after the restoration of the Bourbon monarchy in 1874), anticipating the second restoration of the Bourbon monarchy under Juan Carlos I, who viewers knew was Franco's designated successor.

Turning from context to text, Tormento was a critical and commercial success, attracting over two million spectators and winning the Best Spanish-Language Film award at the San Sebastián Film Festival. This was thanks to the casting of the actors (the experienced Concha Velasco alongside the aspiring progre (radical) Ana Belén and the known Socialist-sympathizer Paco Rabal), their performances, and the adaptation's harnessing of the source novel's explicit melodramatic qualities to the film genre of melodrama. As Velasco's three awards for her role attest, the film owes much of its success to her performance as Rosalía, the slightly dim, middleaged, endlessly scheming petite bourgeoise bent on social ascent, known to Galdós enthusiasts from this novel or its sequel of the same year, La de Bringas (1884). Drawing on her experience in popular comedy, Velasco perfectly judges her portrayal of this shrewish stereotype, presenting Rosalía's pomposity and hypocrisy as objects of satire rather than caricature. Olea and Velasco take full advantage of the prancing, puffing, and preening indicated by Galdós throughout his text (the actress put on eleven kilos to take on the role). A good example is Velasco's performance of the passage in which Galdós describes a conversation between Rosalía and Agustín. With a self-reflexive nod, Galdós' narrator writes that an "attentive observer" would have noted Rosalía's desire to leave her relative in no doubt over her beauty: done up in carefully chosen clothes and accessories, "cómo enseñaba sus blancos dientes, cómo contorneaba su cuello, cómo se erguía para dar a su bien fajado cuerpo esbeltez momentánea" (how she flashed her white teeth, how she showed off the shape of her neck, how straight she held herself to 
make her tightly corseted body look momentarily slender) (Pérez Galdós 1977: 175). Olea is the ideal "attentive observer" and Velasco's interpretation of Rosalía was so successful that the director expanded her role in the film compared to the novel (Navarrete 2003: 136).

The final sequence is especially revealing of Olea's intentions as it departs significantly from the novel. In Galdós' original, we learn that Amparo has become Agustín's mistress when Rosalía's husband Bringas alone sees Agustín off at the station (chapter 40); Rosalía's reaction occurs when Bringas relays the information to her in the following chapter. The novelist can only signal Rosalía's disgust through language: questions, exclamations, and - a Galdós favourite - ellipsis, heavy here with pent-up, unarticulated emotion: "¿Y tuviste paciencia para presenciar tal escándalo? ... Conque no la puede hacer su mujer porque es una ... iy la hace su querida ...!" (And you had the patience to witness such a scandal? ... So he can't make her his wife because she's a ... and he makes her his mistress ...!) (Pérez Galdós 1977: 194). In the film, both Rosalía and her husband turn up at the station to say goodbye. As Ramón Navarrete points out, this draws the adaptation full circle and conveys the impression of a closed world to the viewer (2003: 135), since Olea also eliminates the novel's opening conversation and begins with Agustín's arrival by train. Rosalía is particularly keen to see off a man she believes she has saved from a dishonorable marriage and whom she hopes may be a future son-in-law, if not a second husband for herself. Velasco's gloating gaze at Agustín in the train clouds over with horror when her former maid Amparo steps forward in the carriage (see Figure 17.1), a point emphasized cinematically through the zoom. “PPuta, puta, puta!” (“Bitch, bitch, bitch!”) we hear her furiously mutter (though the script had promised the censors these words would be masked by the departing noise of the train).

Amparo's triumphant gaze is a mirror image of Rosalía's here. Up to this point, Belén's performance as the angelic Amparo - admittedly a less juicy role - had been insipid compared to Velasco, even though the maid's past shadowy love affair with a priest and present rosy romance drive the film narrative. In terms of the diegesis, the final shot of Belén's Amparo is climactic: through it, the viewer learns that Amparo and Agustín will live in sin. But there is an extradiegetic story here too about the two actresses' performance style. The matching shots of Velasco's and Belén's gloating gazes triggers Belén's performance to shift gear from holierthan-thou servant girl to triumphant mistress, as if she had learned from the more experienced actress in the course of the shoot. This apprenticeship would serve her well when she embodied Galdós' most famous heroine, the working-class Fortunata, in Camus' 1980 television series Fortunata y Jacinta - though her performance there is still slightly uneven.

A brilliant Velasco and an improving Bélen aside, another success of Olea's Tormento is its attention to secondary roles. The character of the wealthy relative who returns to Madrid after making his fortune abroad, Agustín Caballero, was hardly a challenge for Paco Rabal, whose star trajectory had included portraying the protagonist of Buñuel's Mexican Nazarin (1959) and the cocksure Jorge of his 


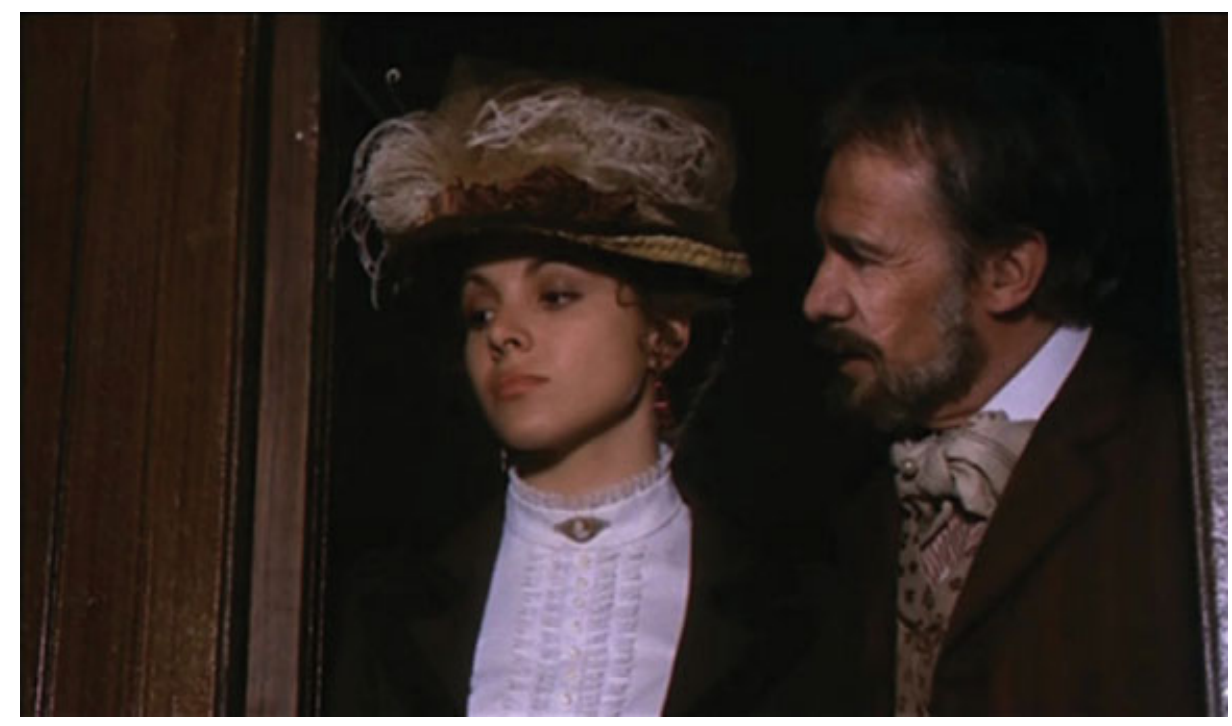

Figure 17.1 Amparo (Ana Belén) gazes triumphantly as Agustín (Paco Rabal) draws her into view in Tormento (Pedro Olea, 1974; prod. José Frade PC).

Spanish-made Viridiana (1961), subsequently going on to earn his colors with major European and Latin American auteurs such as Michelangelo Antonioni, Claude Chabrol, Leopoldo Torre Nilsson, and Glauber Rocha. Rabal's career, with his extensive experience of filming overseas, felicitously matched his on-screen role in Tormento as the self-made Agustín whose career has been forged in the Americas. As Rabal's Agustín draws Belén's Amparo into view for the triumphant final shot described above, it again seems that an older generation of veteran actors is guiding a younger generation forwards.

It has frequently been stated that the nineteenth-century novel provided fiction film with its (realist) narrative codes. Galdós' Tormento demonstrates that it provided film with a model for melodrama too (a genre explicitly referenced in the novel's parodic first chapter). Olea reads his source text through the lens of the female-focused narratives, theatrical performance style, and narrativized mise-enscène of film melodramas made in Hollywood (e.g., Douglas Sirk) and Spain (e.g., Miguel Picazo). The film's mise-en-scène in general and costume in particular illustrate this influence. Setting reinforces characterization, inviting viewers to contrast the tacky pretentiousness of the Bringas' apartment with the austerity of Amparo's home and the grandeur of Agustín's mansion. But the use of costume is multi-layered. In the light, perhaps, of the attention given to dress in the sequel novel, La de Bringas, Olea expands on Galdós' mention that Rosalía takes charge of purchasing Amparo's new clothes following the announcement of her engagement to Agustín (Pérez Galdós 1977: 129). Costume is narrativized as Amparo's shift from servant to Señora is registered in her dress. But for Rosalía this is about 
control. Amparo may have won the battle for Agustín, but Rosalía will win the war of clothes: Rosalía accuses Amparo of lacking "taste" and "style" (those ultimate signifiers of class) (Pérez Galdós 1977: 129, 134) and takes more care to dress sexily herself, in the home and out, following the engagement (135). As the example of Amparo's attire in the last scene demonstrates, Rosalía's attempt to pin her down and hem her in through clothes fails. Olea, working in a visual medium and a genre attentive to mise-en-scène, is able throughout the film to capitalize on this power-dressing.

\section{El perro del hortelano / The Dog in the Manger (Pilar Miró, 1996)}

Olea's Tormento and Pilar Miró's El perro del hortelano are separated by the explosion in the number and popularity of classic adaptations - known collectively as "heritage film" (Higson 2003) - in the 1980s. These included Merchant Ivory productions and quality British television adaptations. This trend was echoed in 1980s Spanish cinema. However, these "Miró" films - so named since they were financed by the subsidies for quality cinema introduced by Pilar Miró in 1983 when Director General of Film, a post she held from 1982 to 1986 - perform an awkward balancing act that distinguishes them from their foreign counterparts. While adopting the high production values often used to portray the aristocracy in European heritage movies, Spanish classic adaptations of this period take as source texts the gritty, politically oppositional texts of Spain's fraught twentieth century, which tend to focus on the poor (e.g., Francesc Betriu's 1985 adaptation of Sender's Réquiem por un campesino español / Requiem for a Spanish Peasant). The term "heritage film" can thus be used of Spanish classic adaptations of this period only with qualifications. Despite the awkwardness of some of these films, and the fact that successes such as Tormento were forgotten in the desire to dismiss culture produced under the dictatorship once democracy arrived, classic literary adaptations continued to find audiences in the 1990s and after. Mirós 1996 film version of Lope de Vega's 1618 play El perro del hortelano is a key example.

Like Olea, Miró was a graduate of the Madrid Film School and a director for whom literature and film went hand in hand. Apart from her support for literary adaptations when Director General of Film and subsequently (1986-9) Director of Spanish State Television (TVE), her own filmography includes five adaptations plus television work in this area. El perro - which attracted almost a million viewers in Spain, earned over three million euros in box-office receipts, and received twelve awards including seven Goyas - pulled off what many saw as its audacious retention of almost all of Lope's original verse: only one fifth is cut (Allinson 1999: 35).

Miró's work builds on the 1980s boom in adaptations of literary classics. Press reviewers of the 1990s were writing for a very different readership from those who reviewed Olea's film in 1974 - a readership that was cine-literate, internationally aware, and sensitive to gender issues. With the odd exception (Monterde cited in 
Evans 1997: 9), press reviews echoed the enthusiasm indicated by high audience attendance and awards. Critics praised the adaptation for its fidelity (Bermejo 1997; Canning 2005: 82) and its successful deployment of cinematic techniques (Riambau cited in Evans 1997: 9). Following prompts from Miró herself regarding her admiration for international heritage cinema - Cyrano de Bergerac (Jean-Paul Rappeneau, 1990), an obvious model also scripted entirely in verse, and Much Ado about Nothing (Kenneth Branagh, 1993) were mentioned by her in interviews of 1995 and 1997, before and after the film's premiere, respectively ( $\mathrm{Paz}$ 2001: 259; Fernández Soto and Checa y Olmos 2010: 86) - critics hailed the film as the first Spanish movie to rival these foreign successes (García-Posada 1997). Miró also guided critics toward an interpretation of the film as a reworking of Lope that is sensitive to gender critique (Torres 1997).

If Tormento, made in 1974 on the eve of the transition, appeared when the chief concern was the need to redefine political identities rather than gender issues, a very different feminist politics of identity, appropriate to the changed historical context of the 1990s, emerges as central to El perro. As an example of Spain's modest heritage cinema (Perriam 2003: 85), Miró's film is usefully interpreted through theoretical work on this trend. In terms of form, Ginette Vincendeau argues that what differentiates heritage cinema from earlier period films (thus $E l$ perro from Tormento) is, first, an emphasis on setting and, second, a "mannerist and postmodern" self-consciousness about narrative conventions (2001: xviii). In terms of ideology, critics of the prominent British heritage cinema - Charles Barr (1986: 11) coined the term and Higson has subsequently focused specifically on "English heritage" - and of its limited Spanish equivalent concur that "there is a tension between narrative and spectacle," the former "progressive" and the latter "reactionary" (Smith 2006b: 111-12). Weighing Vincendeau's identification of formal characteristics against this ideological tension, the following analysis will argue a case for interpreting Miró's period picture as a feminist text that, in its knowing adoption of heritage form, exhibits the reflexivity that is central to postmodern cultural production.

In accordance with the first characteristic outlined by Vincendeau, mise-enscène is fundamental to El perro. The vibrant costumes worn by Emma Suárez's Diana, and the sumptuous interior and exterior settings of her palace, are a major source of visual pleasure. However, this is not a "museum aesthetic" (Vincendeau 2001: xviii) where narrative depth is displaced by surface spectacle, because this mise-en-scène is made to serve the narrative. We do not just marvel at the frills and bustles of Diana's dresses, which in any case were not authentic - they date from the mid-seventeenth century whereas the play is from 1618 (Canning 2005: 84). Dress is clearly aligned with plot development, as the colors of Diana's costumes encode emotion: blue for coldness; red for passion; gold and orange at the opening and conclusion for social status (Canning 2005: 90). Settings similarly enhance the narrative: palatial interiors reference Diana's social standing; exteriors in the garden express a loosening of restrictions that allows her to flirt with her secretary 
(Canning 2005: 84). The director capitalizes too on the liminal spaces that connect these two spheres, such as the steps, and on fluid spaces such as the river (Allinson 1999: 36). If the inauthenticity in costume may have been lost on audiences, newspaper readers would have been aware of the inauthentic locations since Miró explained that the film was shot in Portugal because permits were easier to obtain there (Evans 1997: 9). This geographical displacement has the additional advantage of making it clear that the faithful portrayal of period was not Mirós concern. Thus the film does not fully comply with Vincendeau's view of the heritage movie's attitude to setting, since it avoids the superficial stress on spectacle that scholars have criticized.

If we turn to Vincendeau's second formal definition of heritage film - its reflexivity - an analysis of performance style in El perro allows us to appreciate how the film promotes a progressive narrative in gender terms. If Velasco, Belén, and Rabal made Tormento a success, so Emma Suárez and Carmelo Gómez account for much of El perro's appeal. But, while Velasco's intelligent performance can be attributed to her previous work in popular film and Rabal's to his experience in auteur cinema, Suárez's and Gómez's success is best appreciated through their recourse to the acting conventions of foreign heritage cinema. Chris Perriam argues that Gómez's costume, long hair, and beard self-consciously echo Gérard Depardieu's look in Cyrano de Bergerac, while the delivery of his lines is knowingly "postmodern" (2003: 85). In the case of Suárez, the intelligence that actresses such as Emma Thompson have brought to British heritage cinema is surely a model. Elaine Canning argues that Miró's Diana is "a more coquettish creature than her Lopean counterpart" (2005: 84), and, while we cannot know how a seventeenthcentury stage actress would have performed this role, Canning's point regarding Suárez's performance stands. Breathless, wistful, or lusty by turns in her delivery of Lope's lines, Suárez's Diana oozes intelligence and self-awareness. Crucial here for a gendered interpretation is Suárez's "mannerist" performance - playfully peeping through her veil at mass, or suggestively clutching a rose as she muses "Mil veces he advertido en la belleza, / gracia y entendimiento de Teodoro; / que a no ser desigual a mi decoro, / estimara su ingenio y gentileza" (I’ve noticed a thousand times in Teodoro's beauty, grace and wit that, if it were not inappropriate to my sense of decorum, I might admire their ingenuity and gallantry) (Vega 1991: 68) (see Figure 17.2). This ensures that her coyness merges suggestively with cunning, making her role satisfying to feminist audiences in Spain, who since 1975 have enjoyed increasing numbers of films (by women and otherwise) that "articulat[e] the changing definitions of female subjectivity and the relations between the sexes" (Evans 1997: 12). El perro, then, adapts the characteristics of the heritage trend to suit its purpose. By playing down the genre's "museum aesthetic" and playing up its self-consciousness, Miró avoids the seductions of surface and foregrounds a feminist reading of Lope's play.

While the film only partially adopts the formal characteristics of foreign heritage, its success is explained by a more consistent generic affiliation with romantic 


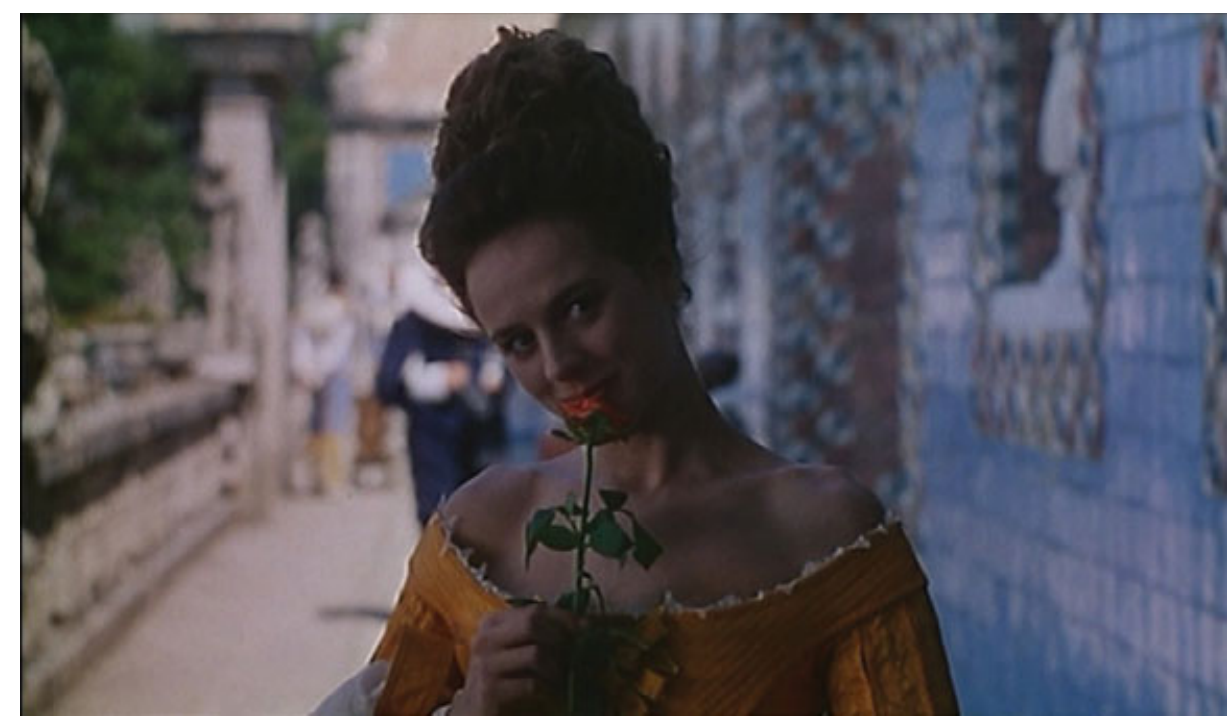

Figure 17.2 Emma Suárez's knowing performance as Diana in Pilar Miró’s film version of Lope de Vega's El perro del hortelano (1996; prod. Enrique Cerrezo Producciones Cinematograficas).

comedy (Evans 1997: 10-11; Allinson 1999: 34). It is relevant in this context that Branagh's Much Ado, one of Miró's models, was also marketed as a romantic comedy. Thus, the Portuguese palaces that provide the setting evoke romantic comedy's recourse to a lovers' "place apart" (Evans 1997: 10), while the cinematography portrays the unfolding of romance through the point-of-view shots, facial close-ups, dissolves, and soft-focus photography that are typical of the genre (see Allinson's (1999: 37) formal analysis of the end of Act II). The opening kiss between Teodoro and Diana's love rival Marcela - a departure from the play (Canning 2005: 83) - also signals the romantic comedy genre. Just as it is helpful to consider Tormento as a melodrama, analyzing El perro as a romantic comedy highlights its intelligent use of film technique. Mark Allinson goes so far as to suggest that the film does not belong to the heritage category at all (1999: 34). It can be argued that El perro's generic mix of heritage movie and romantic comedy reveals the film's indebtedness to the 1990s contexts of feminism and postmodernism.

\section{Literary Adaptations: Methodological Conclusions}

If we take a literary adaptation to be an "extended, deliberate, announced revisitation of a particular work of art" (Hutcheon 2006: 170), comparison is bound to be the business of adaptation studies. Since a literary adaptation is first and foremost a film, that comparison must be shaped by the methodology of film studies rather 
than of literary studies. This avoids the potential to close down interpretation implied in the approach proposed by Seymour Chatman in 1980 in his essay entitled "What Novels Can Do that Film Can't (and Vice Versa)." The analysis here of Tormento and El perro has been guided by questions raised by film studies: casting, star image, performance style, generic traits of melodrama and film comedy, and (in so far as is possible) reception. Such an analysis shows Olea, in collaboration with his actors and technical crew, to be an "attentive observer" of his source novel, who capitalizes on the performance and star images of actors such as Velasco, Belén, and Rabal (associated with comedy, lost innocence, and world-weariness, respectively) and draws on conventions of mise-en-scène typical of melodrama (the use of interior spaces and clothes) to infuse Galdós' literary text with a cautious critique of class and gender roles in the twilight of the dictatorship. Miró's collaboration with her actors and technical crew may be likened to that of a theater director - her work in the theater in the early 1990s is relevant here (Fernández Soto and Checa y Olmos 2010: 86). Her familiarity with theater as performance art allows her to elicit Suárez and Gómez’s knowing delivery of Lope’s lines, and to dress, accessorize, and position them within the frame in playful response to the text. But El perro could not be further from filmed theater: the formal characteristics of romantic comedy as a film genre, especially settings and cinematography, enrich performance style and mise-en-scène to offer a reflexive, feminist reworking of the 1618 stage original.

\section{Film and Television (Paul Julian Smith)}

Anyone reading the Spanish press in 2009 could be excused for thinking that the audiovisual sector was in a critical condition. Journalists and filmmakers predicted the death of Spanish cinema, which had been identified by the director of the Ministry of Culture's Instituto de la Cinematografía y de las Artes Audiovisuales (ICAA; Institute of Film and Audiovisual Media) as the "image" or "calling card" of Spain to the world (G. B. 2009). While the traditional foe of the film industry was always Hollywood, there was now also an enemy within: television. A Supreme Court judge had ruled that the substantial subsidies paid by the television channels to film producers, legally enforced by the government in its recently renewed Cinema Law, were unconstitutional. How, then, asked press and industry alike, could Spanish national cinema survive this new betrayal by the upstart electronic medium (García 2009)?

El País cited veteran Fernando Bovaira, producer of Alejandro Amenábar's successful feature Agora (2009), on the negative prognosis for the film industry in Spain if it was indeed deprived of financial support from the television business. The article noted that television companies had been obliged since 1999 to invest five percent of their income in film, and that in 2007 that sum had risen to as high 
as 153 million euros (García 2009; see Chapter 14). The television companies replied that the practice had been "arbitrary" - if filmmakers received subsidies from television, why not sportsmen or dentists? Ironically, 2009 had proved to be a record-breaking year for Spanish cinema at the box office, with the historical epic Agora joining forces with genre films such as prison drama Celda 211 / Cell 211 (Daniel Monzón); teen movies Mentiras y gordas / Sex, Party, and Lies (Alfonso Albacete and David Menkes) and Fuga de cerebros / Brain Drain (Fernando González Molina); and Pedro Almodóvar's typically polished melodrama Los abrazos rotos / Broken Embraces.

Historians of Spanish film have commented that this rhetoric of "crisis" has been constant in a field known throughout its history for "unrelieved industrial decapitalization" (Hopewell 1986: 4). The repeated predictions of the death of Spanish cinema have thus been greatly exaggerated. Moreover, as scholars such as Josep Lluís Fecé and Cristina Pujol (2003) remarked of a now forgotten cinema scare that had taken place as recently as 2001-2, a financial crisis for current industry practitioners should not be conflated with a crisis for all those groups who are stakeholders in Spanish cinema; to put it more plainly, unlike producers, spectators do not benefit from the production of feature films that fail to connect with the audiences for whom they are supposedly intended. Fecé and Pujol wrote rather of an "imaginary" crisis for a "cinema without an audience" (2003: 147-65).

While the polemic between the two media was especially acute in 2009 , rivalry between them has been continuous since regular television broadcasting began in Spain at the late date of 1956. And I shall suggest, against received wisdom, that cinema has been for some time dependent on television, not just industrially but also artistically. In their monumental history of producers in Spanish cinema, Esteve Riambau and Casimiro Torreiro argue that the period since 1995, when the Law for the Protection and Promotion of Cinema first came into effect, should be called "the era of the audiovisual"; cross-subsidies combined with the consolidation of "the great [media] conglomerates" meant that it no longer made sense to speak of a separate "film industry" and "TV business" in Spain (2008: 901). Using the evidence of parallel case studies of audiovisual products, I have argued myself in a recent book (Smith 2009a) that the convergence between the two media, both commercially and aesthetically, suggests that they can no longer be considered in isolation from one another.

Before tracing this somewhat fraught history, let us begin with a brief industrial survey of the current conditions of the two media. In all three areas - production, distribution, and exhibition - the first decade of the twenty-first century had been a success story for the Spanish film industry. To take some statistics from the official source of the Ministry of Culture website (Ministerio de Cultura n.d.), feature film production fell to a low of forty-seven in 1990, but by 2006 it had risen to 209; the audience for those Spanish films was 13.9 million in 1997, but by 2005 it was 21.29 million, giving the industry an enviable market share of 20.35 percent; due to the belated multiplexing of Spanish theaters, the number of screens more than 
doubled in the decade between 1996 and 2005. Although television had been instrumental in the collapse of cinema-going as a mass activity in the late 1960s and the 1970s, it seemed that Spaniards had now been tempted back into the movie theaters in spite of the proliferation of offerings on the small screen.

If this cinematic success has been somewhat obscured by pessimistic journalists or self-interested professionals, then the blossoming of television fiction remained almost unknown outside limited academic circles in Spain, such as the research groups headed by Lorenzo Vilches in Barcelona and Manuel Palacio in Madrid. Since the early 1990s the production of quality local fiction, spearheaded by the autonomous communities of Catalonia and the Basque Country (less innovative in feature film than in television fiction), has pushed once-dominant US series to the margins of the schedule. Milly Buonanno's Euro Fiction Group has noted that the number of hours taken up by local production nearly tripled between 1996 and 2001, far outstripping France and Italy, and that Spain has a higher seriality index than those nations, meaning that it produces more episodes of single titles for faithful fans (Eurofiction 2007). In spite of competition from the Internet, those viewers watched more television than ever in the first decade of the new millennium. In 1993, women viewed on average 223 minutes a day; by 2005 the figure had risen to 246, one of the highest in Europe (Rueda Laffond and Chicharro Merayo 2006: 449). With the exportation of innovative fiction formats such as period drama - for example, Cuéntame cómo pasó / Tell Me How It Happened (TVE-1, 2001-) - Spain had produced a mature industry of primetime weekly series whose production values were much higher than Latin American telenovelas (soap operas, usually running for a fixed period unlike the British and US variety) and that could be compared only to the fiction factories of Hollywood (see Figure 17.3).

It was Raymond Williams, father of British cultural studies, who first called attention to the paradox of the audience's early preference for television over film in spite of the former's "visual inefficiency" (1990: 28). Viewers were prepared to accept the technical impoverishment of the small screen with its flickering black and white image because the new medium was richer in its "social definition" (1990: 29). While cinema was confined to "discrete and specific works" shown in a "special kind of theater," broadcasting was "general” in its content (music, news, entertainment) and was consumed in the "privatized home" in which citizens of the 1950s were increasingly invested (1990: 29). More recent theorists of television have stressed the medium's continuing flexibility. Milly Buonanno writes that "it is precisely because television allows us to switch between looking and listening, between involvement and detachment, and because it offers us both demanding and relaxing form of cultural entertainment and social participation that it can claim to [be] an open medium” (2008: 41).

On a more formal level (but still stressing "openness"), Kristin Thompson argues for "redundant and dispersed exposition" (2003: 37) in television narratives, which, unlike classic movie plots, are often left without definitive closure. Thompson notes, however, the adaptation of films into television series and vice versa (2003: 

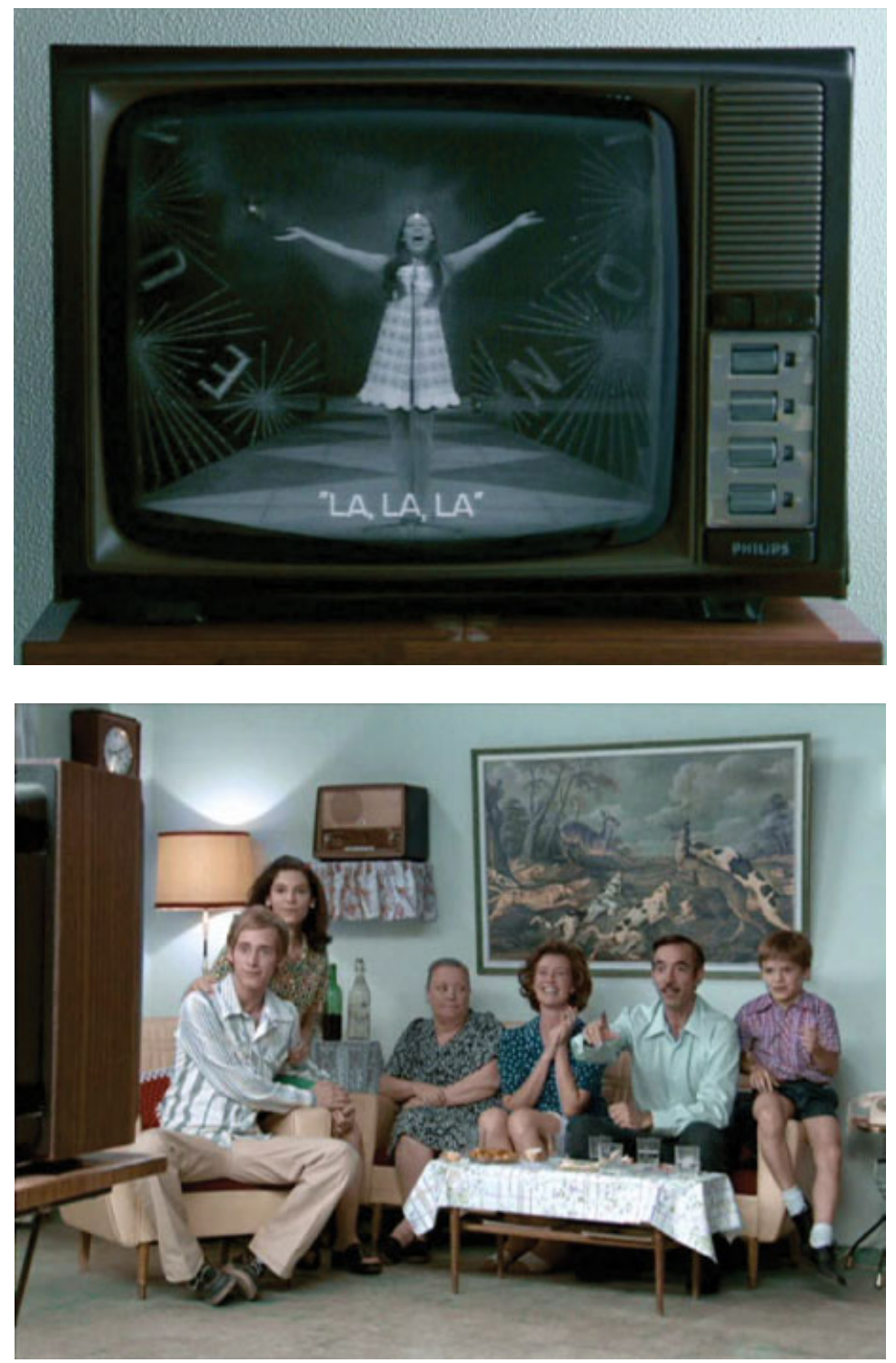

Figure 17.3 The Alcántara family watches Massiel win the Eurovision Song Contest for Spain in 1968, in the first episode of Cuéntame cómo pasó (TVE-1, 2001-).

83-98). On an industrial level, the convergence of the two media has been dissected by Spanish media academics. Enrique Bustamante distinguishes between "vertical integration" within a single medium (when, say, producers take control of distribution); "horizontal integration" (when broadcasters increase their range of stations); and "multimedia integration" (when producers attempt to produce synergy or mutual reinforcement between their products or sectors) (2004: 88). 
In the historical survey that follows, we shall see how each of these questions (of social address, consumption, narrative form, and industrial synergy) has played out in the Spanish audiovisual sector.

After the arrival of broadcast television - rigorously controlled by the state - in 1956, Spanish commentators, more accustomed to film, proved nonetheless open to the artistic possibilities of the new medium. In his introduction to a 1963 book of television scripts by pioneer Jaime de Armiñán - later to direct the remarkable cross-dressing feature Mi querida señorita / My Dearest Señorita (1972) - the critic "Viriato" (penname) cited the already classic live television drama made in the United States by creators such as Paddy Chayefsky and set out to define the televisual medium, which he regarded as a new and unexpected dramatic field (Armiñan 1963: 27). According to media historian Mario García de Castro, Spanish television drama (of which there was already twelve hours a week in 1966 and 1967) was thought at the time to constitute a distinctive "third way" between theater and cinema (2002: 25, 35). As Tatjana Pavlović has noted, it is ironic that the few surviving images of such early fiction (which was either live or wiped) are preserved on film, often in the newsreels that reported on the new medium for cinema audiences (2007: 9).

Curious hybrids also appeared in this early period, crossing the boundaries between media. Pavlović, again, has studied Historias de la television / Television Stories (1965), a comic feature directed by Francoist film veteran Sáenz de Heredia. This film combined the trends of consumerism and modernity with the changing role of women, as illustrated by its female protagonist, the enthusiastic would-be singing star and hopeless housewife played by Conchita Velasco (Pavlović 2007: 15). A lesser-known later example is La casa de los Martinez / At Home with the Martínez (Agustín Navarro, 1971). A curious blend of sitcom and chat show, the television version, which ran from 1967 to 1971, showed a "typical" Spanish family (albeit with two live-in maids) who entertained a celebrity in their home each week, granting them a key to their (televisual) house. The feature film of this show, which was made as the television series came to the end of its run, begins with a curious prologue in which varied households are shown getting ready to watch the show: a butler announces to a posh couple that "the television is served"; a working-class man shouts out of his apartment window to a woman hanging up the washing, alerting her to the start of her favorite program; and a family with eight children solemnly introduce themselves to the camera before settling down to watch.

This imagined community of television viewers is, in the feature film that follows, undercut by the anxieties provoked by the new medium. Old-fashioned Señor Martínez fears, given his wife's new stardom and the close attentions of the series' director, that he is no longer master in his own house. A relaxing trip to the country, away from the bright lights of celebrity-plagued Madrid, is ruined when even the village hicks recognize Spain's most heartwarming family and insist on loudly celebrating the latter's presence among them. There is a constant refrain 
in the dialogue here that Spain has to modernize and become European. It is a process identified with feminism, modernity, and television itself that seems at once desired and feared. Film audiences of the time (almost half a million saw this feature) were no doubt also disconcerted to see their domesticated friends, hitherto glimpsed in blurry black and white, displayed in full color on the big screen of their local picture palace. The "visual inefficiency" of television noted by Williams was here partially eclipsed by the technical superiority of a film medium that lacked, nonetheless, the "social definition" of its younger rival. Much later, television would return the favor to Francoist cinema: since 1995, TVE-1 has devoted Saturday afternoons to the screening of a feature film of the dictatorship in a slot known significantly as Cine de barrio / Neighborhood Movie Theater.

According to Manuel Palacio, the 1960s and the first half of the 1970s marked the "golden age" of Spanish television drama (as the 1950s did for the United States). Commentators even lamented that, with the end of live performance in the studio, the "distinguishing characteristic" of television drama had been lost (Palacio 2001: 86). Palacio gives a list of some thirty distinguished cineastes who worked for television at the time (2001: 87); and, taking advantage of the relative freedom of the minority second channel (TVE-2, which began broadcasting in 1966), future film directors such as Pilar Miró and Josefina Molina produced some of their riskiest works for the small screen, which proved to be a more open medium than cinema even under the dictatorship (Palacio 2001: 132).

While Palacio states that television fiction has always had a logic distinct to that of film and theater (2001: 143), he also recounts radical changes in the medium. For example, at the time of the transition to democracy, the studio-bound drama of the 1970s (one distinguished and long-lasting slot was actually called Estudio 1) gave way to the classic prestige serials of the 1980s (often literary adaptations), which were shot on celluloid and used feature film techniques (Palacio 2001: 153; see the previous section of this chapter). Such series not only played a vital pedagogic role, educating Spaniards in the new ideals of democracy; they also offered some explicit space for radical politics, not always present in film of the period. According to director Josefina Molina, Teresa de Jesús / Teresa of Ávila (TVE-1, 1984), again starring Concha Velasco, reworked a Counter-Reformation heroine in order to celebrate women's freedom of initiative (Palacio 2006: 102). Faulkner has noted the complex multimedia dialogue between novels of the nineteenth century, their film adaptations in the 1970s, and the television versions of the same works in the 1980s (2004: 81).

Yet television auteurs thrived in very different technical and institutional conditions. Narciso Ibáñez Serrador's gothic series Historias para no dormir / Stories to Keep You Awake (TVE, 1966-8) exploited the gloomy claustrophobia of studio sets to scare Francoist audiences, and Antonio Mercero's more expansive and optimistic location-shot serials, some of the best-known titles in Spanish television history, warmed the hearts of viewers in the dictatorship (Crónicas de un pueblo / Chronicles 
of a Village (TVE, 1971-3)) and the new democracy (Verano azul / Blue Summer (TVE-1, 1981)). While both directors also worked in feature film, they remain best and most fondly remembered for their innovative work in television (see Smith 2009a: 145-74). Much later, in a cinematic tribute to his low-budget television dramas, five film directors (Álex de la Iglesia, Jaume Balagueró, Mateo Gil, Enrique Urbizu, and Paco Plaza) were to join Narciso Ibáñez Serrador in making featurelength fictions that were released under the umbrella title Peliculas para no dormir / Films to Keep You Awake (2006).

As we have seen, feature film production fell to a record low in Spain at the end of the 1980s, the same decade in which prestige television series took on cinematic production values. But the much-delayed launch of commercial television in Spain at the start of the 1990s led to a perceived decline in quality and a controversy over so-called telebasura (junk television). One unique figure in the crossover between film and television here is "popular auteur" Álex de la Iglesia. As Buse, Triana Toribio, and Willis have argued in their excellent monograph on the director (2007: 61), De la Iglesia pays affectionate homage to television, citing horror auteur Ibáñez Serrador in his black comedy El dia de la bestia / The Day of the Beast (1995). And yet, de la Iglesia's plot, in which a phony television medium joins forces with an eccentric priest, is clearly a savage satire on private television, with the film's fictional "Tele 3" combining the names of the two principal real-life commercial channels Antena 3 and Telecinco (Buse et al. 2007: 73).

As I have documented elsewhere, Almodóvar reveals a similar ambivalence to the small screen (Smith 2006a: 143-56). While his early features of the 1980s gleefully celebrate television genres such as commercials and, indeed, popular culture in general, Almodóvar has made a continuing attack on the medium since his critique in Kika (1993) of the new genre of reality shows, the supposed epitome of telebasura. The social presence of the medium is such, however, that it has remained ubiquitous in his cinema (see Figure 17.4). It is perhaps no accident that both de la Iglesia and Almodóvar have dabbled (with mixed results) in the production of television series that were screened on TVE-2, the minority public channel: El Deseo made the working-class dramedy Mujeres / Women (2006) while de la Iglesia wrote and directed the sci-fi sitcom Plutón B. R. B. Nero (2008-9).

In 2000, Richard Maxwell, the Cassandra of Spanish television studies, claimed that a multi-channel environment would lead to "unprecedented demand for imported films and television shows from Hollywood" (2000: 176) and a "decline in the quality and timeliness of domestic productions broadcast free of charge" (2000: 177). Fortunately, this has not proved to be the case. Writing in 2007, Vilches noted that, even after the introduction of two new national channels into a crowded marketplace (Cuatro and la Sexta), local television series still dominated in the schedule over feature films, especially in prime time and on stations with a national reach (2007: 165). Moreover Telecinco, then the frontrunner among all the channels, owed its success mainly to its home-produced quality dramas, a tradition that stretched back to the start of the previous decade. It is perhaps no 


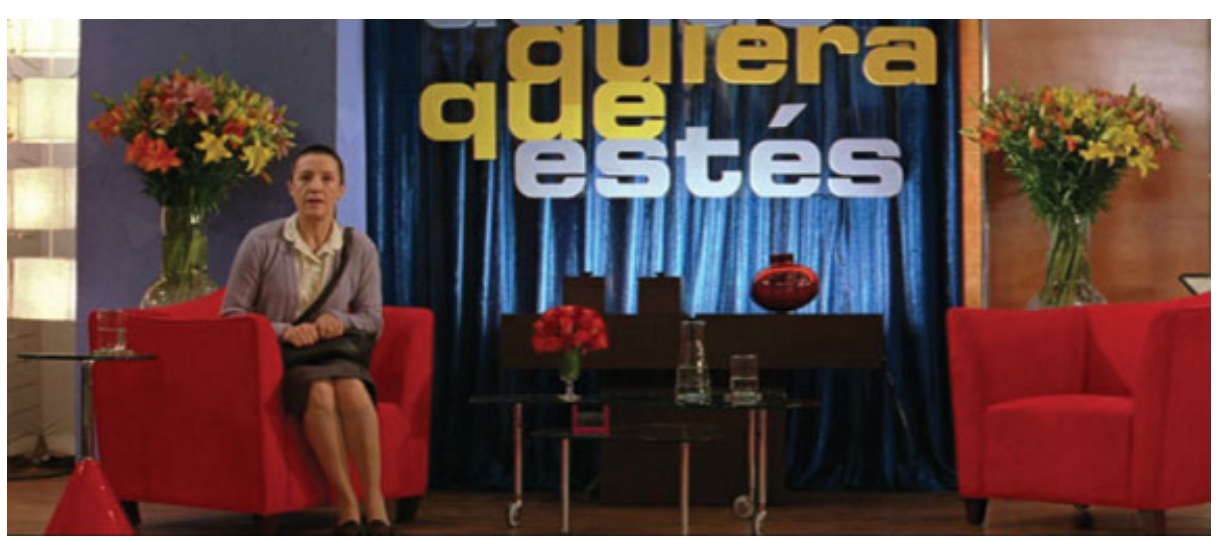

Figure 17.4 Pedro Almodóvar’s Volver (2006; prod. El Deseo): Agustina (Blanca Portillo) appears on television.

surprise, then, that the influence of television should be felt so strongly in the content of feature films of the new millennium.

Let us look more closely at the year 2009, which boasted a number of innovative new titles in television fiction (Smith 2009b). As mentioned earlier, the most popular domestic feature films for that year, far out-grossing even an established auteur such as Almodóvar, include Mentiras y gordas (a teen melodrama boasting copious quantities of drugs and sex) and Fuga de cerebros (a teen comedy reveling in crude jokes on such topics as blindness and necrophilia). While these commercial hits are often dismissed as mere facsimiles of their US generic equivalents (in this case, youth movies), unlike art films they receive no distribution abroad and are thus precisely targeted to uniquely Spanish audiences. They thus encourage the national "social participation" that is for Buonanno characteristic of television fiction.

Moreover, the principal selling point of such popular cinema is the presence of young actors familiar to audiences only from domestic television. While the Spanish edition of Cahiers du Cinéma complained of the "servidumbres televisivas" (servility to television) that it discerned in the more high-minded of the current crop of Spanish film releases (De Pedro and Monterrubio 2009), the more populist Fotogramas celebrated multimedia integration with a feature promoting no fewer than thirteen of what they baptized "teletalentos made in Spain" (homegrown television talents) (Fotogramas 2009). The mise-en-scène of this glossy photo spread is an unlikely classroom where young actors with "un pie en el cine" (one foot in the cinema) (Fotogramas 2009: 104) are being lectured on the technical terms of television: a blackboard boasts such anglicisms as "share," "primetime," and "late night" written in chalk. The brief biographies that follow in the text accompanying the image give the fledgling stars' credits in television first, then in film. Rarely has media convergence been more self-evident. 
A special case in this context is Mario Casas, the leading actor in both of the teen feature films mentioned above, whose previously supporting role in Antena 3's quirky ensemble police series Los hombres de Paco / Paco's Men (2005-10) was punched up to coincide with his new status as a cinematic leading man. Hoping for synergy in spring 2009, the channel aired frequent cross-promotions of Fuga de cerebros in the advertising breaks for this series. Given that most Spanish films fail to appeal to the teenage demographic that comprises the most assiduous group of visitors to cinemas, the success of local youth movies of this kind, which attract audiences in their millions, is no small achievement. Such successes also contradict the "crisis" narrative of Spanish film promoted by more mature producers and journalists, who are, of course, temperamentally hostile to youth movies.

These films no doubt benefited from the disrobing of their young stars' bodies, which are kept somewhat better covered on television. And it is striking that, in these parallel narratives that cast the same actors across two media, it was the television fiction that was more mature in its coverage of social issues. Thus, the premise of the film Mentiras y gordas (which could have been unchanged since the 1960s) was that Mario Casas' character was a closeted gay youth, doomed to a tragic death because of his unavowed love for his straight best friend. Yet, in the television high-school drama Física o quimica / Physics or Chemistry (Antena 3, 2008), one of the main training grounds for the casts of these youth pictures, a central gay character was treated with much greater sophistication, well integrated with his peer community, and even rewarded in spring 2009 with a steady boyfriend (most of the heterosexual characters in the series have failed relationships).

To take another pressing social issue, Spanish cinema has produced in the last decade of the twentieth century and the first of the twenty-first a restricted number of feature films on the theme of immigration. These are much studied by Hispanists abroad (e.g., Santaolalla 2005) but are little seen in Spain itself. In the same period, long-running television series such as El comisario / The Police Chief (Telecinco, 1999-2009) and Hospital Central (Telecinco, 2000-) have produced a corpus of several hundred episodes dealing with the same theme, all of which were seen by audiences in their millions. More sensitive than feature films to changing social circumstances, these series also trace a shift in the representation of immigrant and ethnic-minority characters from criminals and victims to authentic individuals. Increasingly fused with the host society, they now inspire not repulsion but sympathy and empathy (Lacalle 2008: 124-5).

Such series exemplify the concepts of Buonanno, doyenne of European television studies. They embody cultural proximity, engaging a unique closeness to local audiences, and operate a process of "indigenization," whereby US genres, such as the medical drama or police procedural, are radically adapted and adopted by the various national networks. Serving as both cultural entertainment and social participation, they also employ Thompson's technique of "dispersed exposition" (2003) through the mouthpieces of their large ensemble casts and set in motion multiple plot strands that, unlike goal-directed movie plots, resist simple resolution. 
Spanish television drama is also known for its attention to the past. The public channel TVE-1's weekly series Cuéntame cómo pasó (2001-) and daily serial Amar en tiempos revueltos / Loving in Troubled Times (2005-) have both investigated for mass audiences the texture (and sometimes the terror) of everyday life under Francoism. Such shows are at once demanding in their depiction of real trauma and relaxing in the familiarity of the fictional world they recreate for viewers. Critics who complain of historical "amnesia" in contemporary Spain would do well, then, to pay more attention to this very visible national narrative, which is embedded not in cinema or literature but in television.

One unintended effect of the financial transfers from television to cinema has been the recent rise of a television genre that owes much in its form to film: the historical miniseries. Spring 2009 boasted no fewer than three projects that depicted for the first time on screen the figure of King Juan Carlos. The most notable of these, and the most widely watched program of all time on Spanish television, was TVE-1's 23F: El día más difícil del Rey / February 23rd: The King's Most Difficult Day, which recreated the attempted coup d'état that took place in 1981. As the King, the distinguished theater veteran Lluís Homar combines sympathy for a man betrayed by the generals whom he believes to be his friends with respect for the man who remains Spain's head of state.

By coincidence, Lluís Homar also played the male lead in the highest-profile international release in Spanish cinema that year, Almodóvar's Los abrazos rotos, which premiered just days after the miniseries screened. Both texts seek to explore the past in their different ways and media. Indeed, both contain scenes in which the dignified Homar engages in a kind of personal pedagogy with a younger male, who is (or will prove to be) his son. It is an educational process, which, as Manuel Palacio has suggested (2001), is more often undertaken on television than in cinema in Spain. It is no accident that the year 2009 also saw the publication of two excellent books on the representation of history in Spanish television fiction (López et al. 2009; Rueda Laffond and Coronado Ruiz 2009). Another volume, published in the same year, which treats "discourses of the national on global television," also devoted substantial space to content from Spain, including the televisually rich autonomias of Catalonia and the Basque Country (Castelló et al. 2009).

The link between film and television is thus industrial (the television companies fund both media), generic (popular movies and television series are mutually reinforcing), and artistic (young television-trained actors venture for the first time on to the big screen, even as established film stars cross over to television, attracted by the steady work in series). The well-known virtues of television (its familiarity, domesticity, and cultural closeness to a local audience) might thus well be imitated in a film medium that has sometimes turned its back on national spectators.

While critics and viewers have reason to fear vertical and horizontal integration in the audiovisual sector (which tends to increase monopolies in and across production and distribution), multimedia corporations have still produced some of the most distinguished work of recent years in Spain. To take just one example, 
Telecinco has through its production arm Estudios Picasso created some of the best-quality television drama and some of the most challenging feature films (such as Guillermo del Toro's El laberinto del fauno / Pan's Labyrinth, 2006). There seems little doubt that, in spite of persistent rumors of its demise, cinema will continue to be the calling card of Spain to the world. It is likely, however, that television fiction will remain the mirror that reflects back to local viewers the image that they most recognize of themselves.

\section{References}

Allinson, M. (1999) Pilar Miró’s Last Two Films: History, Adaptation and Genre. In: Rix, R. and Rodríguez-Saona, R. (eds.) Spanish Cinema: Calling the Shots. Leeds: Trinity and All Saints, pp. 33-45.

Altman, R. (1996) Otra forma de pensar la Historia (del cine): Un modelo de crisis. Archivos de la Filmoteca 22: 6-19.

Armiñán, J. de (1963) Guiones de TV. Barcelona: Rialp.

Arroita Jauregui, M. (1974) Galdós como coartada. Arriba (September 4): n.p.

Barr, C. (1986) Introduction: Amnesia and Schizophrenia. In: Barr, C. (ed.) All Our Yesterdays: Ninety Years of British Cinema. London: BFI, pp. 1-30.

Benjamin, W. (1982) Das Passgen-Werk. Frankfurt: Suhrkamp.

Berkowitz, H. (1948) Pérez Gáldos: Spanish Liberal Crusader. Madison: Wisconsin University Press.

Bermejo, A. (1997) Fiel, sobria y brillante. El Mundo (January 25): 3.

Bluestone, G. (1957) Novels into Film: The Metamorphosis of Fiction into Cinema. Berkeley: California University Press.

Buonanno, M. (2008) The Age of Television: Experiences and Theories. Bristol: Intellect.

Buse, P., Triana Toribio, N., and Willis, A. (2007) The Cinema of Álex de la Iglesia. Manchester: Manchester University Press.

Bustamante, E. (2004) La televisión económica. Barcelona: Gedisa.

Canning, E. (2005) “Not I, My Shadow”: Pilar Miró’s Adaptation of Lope de Vega's The Dog in the Manger (1996). Studies in European Cinema 2 (2): 81-92.

Cartmell, D. and Whelehan, I. (eds.) (1999) Adaptations: From Text to Screen, Screen to Text. London: Routledge.

Castelló, E., Dhoest, A., and O'Donnell, H. (2009) The Nation on Screen: Discourses of the National on Global Television. Newcastle: Cambridge Scholars.

Chatman, S. (1980) What Novels Can Do that Film Can't (and Vice Versa). Critical Inquiry 7 (1): 121-40.

De Pedro, G. and Monterrubio, L. (2009) Servidumbres televisivas. Cahiers du Cinéma España 23 (May): 50.

Eurofiction (M. Buonanno and the European Audiovisual Observatory) (2007) Television Fiction in Europe (November 18). Online at: www.obs.coe.int/oea_publ/eurofic (accessed June 6, 2010).

Evans, P. (1997) From Golden Age to Silver Screen: The comedia on Film. Papers in Spanish Theater 5: 1-13. 
Faulkner, S. (2004) Literary Adaptations in Spanish Cinema. London: Tamesis.

Faulkner, S. (2006) A Cinema of Contradiction: Spanish Film in the 1960s. Edinburgh: Edinburgh University Press.

Fecé, J. L. and Pujol, C. (2003) La crisis imaginada de un cine sin público. In: Once miradas sobre la crisis y el cine español. Madrid: Ocho y Medio, pp. 147-65.

Fernández Soto, C. and Checa y Olmos, F. (2010) El cine de Pilar Miró: Homenaje y puente hacia la literatura. Arbor 186 (741): 79-88.

Fotogramas (2009) Generación TV 2009. Fotogramas 1986 (April): 104-11.

García, R. (2009) El cine español no sobrevivirá. El País (December 23). Online at: http:/ / elpais.com/diario/2009/12/23/cultura/1261522801_850215.html (accessed June 6, 2010).

García de Castro, M. (2002) La ficción televisiva popular. Barcelona: Gedisa.

García-Posada, M. (1997) Un perro muy particular. El País (June 2). Online at: http: / / elpais. $\mathrm{com} /$ diario/1997/02/06/cultura/855183606_850215.html (accessed May 22, 2010).

G. B. (2009) La mejor imagen de España. El País (May 29): 50.

Gunning, T. (1986) The Cinema of Attraction: Early Film, Its Spectator and the AvantGarde. Wide Angle 8: 3-4.

Higson, A. (2003) English Heritage, English Cinema: Costume Drama since 1980. Oxford: Oxford University Press.

Hopewell, J. (1986) Out of the Past: Spanish Cinema after Franco. London: BFI.

Horton, A. and Magretta, J. (eds.) (1981) Modern European Filmmakers and the Art of Adaptation. New York: Ungar.

Hutcheon, L. (2006) A Theory of Adaptation. London: Routledge.

Labanyi, J. (1995) Masculinity and the Family in Crisis: Reading Unamuno through Film Noir (Serrano de Osma’s 1946 Adaptation of Abel Sánchez). Romance Studies 26: 7-21.

Lacalle, C. (2008) El discurso televisivo sobre la inmigración. Barcelona: Omega.

Lahoz, I. (ed.) (2010) A propósito de Cuesta: Estudios sobre los comienzos del cine español 1896-1920. Valencia: IVAC.

López, F., Cueto Asín, E., and George, D. R. (eds.) (2009) Historias de la pequeña pantalla: Representaciones históricas en la televisión de la España democrática. Madrid: Iberoamericana.

López Sancho, L. (1974) Tormento, buen espejo galdosiano de situaciones pasadas para realidades de hoy. $A B C$ (September 9): 81.

Maxwell, R. (2000) New Media Technologies in Spain: A Healthy Pluralism? In: Jordan, B. and Morgan-Tamosunas, R. (eds.) Contemporary Spanish Cultural Studies. London: Arnold, pp. 170-8.

McFarlane, B. (1996) Novel to Film: An Introduction to the Theory of Adaptation. Oxford: Clarendon Press.

Ministerio de Cultura (n.d.) Cine y audiovisuales. Online at: www.mcu.es/cine (accessed June 6, 2010).

Moix, T. (1993) Suspiros de España: La copla y el cine en nuestro recuerdo. Barcelona: Plaza \& Janés.

Montiel, S. (2000) Memorias: Vivir es un placer. Barcelona: Plaza \& Janés.

Naremore, J. (2000) Introduction: Film and the Reign of Adaptation. In: Naremore, J. (ed.) Film Adaptation. London: Athlone Press, pp. 1-16.

Navarrete, R. (2003) Galdós en el cine español. Madrid: T\&B Editores.

Palacio, M. (2001) Historia de la televisión en España. Barcelona: Gedisa.

Palacio, M. (2006) Las cosas que hemos visto: 50 años y más de TVE. Madrid: RTVE. 
Pavlović, T. (2007) Television (Hi)stories: “Un escaparate en cada hogar.” Journal of Spanish Cultural Studies 8 (1): 5-22.

Paz, N. de la (2001) Pilar Miró ante el teatro clásico. Anales de la Literatura Española Contemporánea 26 (1): 255-76.

Pérez Bowie, J. A. (2004) La adaptación cinematográfica a la luz de algunas aportaciones teóricas recientes. Signa 13: 277-300.

Peréz Galdós, B. (1977) Tormento. Oxford: Pergamon.

Pérez Perucha, J. (1995) Narración de un aciago destino (1896-1930). In: Gubern, R., Monterde, J. E., Pérez Perucha, J., et al. (eds.) Historia del cine español. Madrid: Cátedra, pp. 19-121.

Perriam, C. (2003) Stars and Masculinites in Spanish Cinema. Oxford: Oxford University Press.

Pingarrón-Esaín, F. (2009) Preparativos para la Exposición Valenciana de 1909: Acuerdos y concursos para ciertas obras, actividades y acontecimientos. In: El Ateneo Mercantil y la Exposición Valenciana de 1909. El espectáculo de la modernidad o la modernidad como espectáculo. Valencia: Ateneo Mercantil, pp. 83-103.

Ramos, P. (1974) Tormento, de Pedro Olea. Alcázar (September 6): n.p.

Riambau, E. and Torreiro, C. (2008) Productores en el cine español: Estado, dependencias, y mercado. Madrid: Cátedra.

Rueda Laffond, J. C. and Chicharro Merayo, M. (2006) La televisión en España (1956-2006). Madrid: Fragua.

Rueda Laffond, J. C. and Coronado Ruiz, C. (2009) La mirada televisiva: Ficción y representación histórica en España. Madrid: Fragua.

Salaün, S. (1990) El cuplé (1900-1936). Madrid: Espasa-Calpe.

Sánchez Salas, D. (2002) En otras realidades: La obra de Clarín, Galdós y Valera en el cine español. In: Heredero. C. (ed.) La imprenta dinámica: Literatura española en el cine español. Madrid: Academia de las Artes y las Ciencias Cinematográficas de España, pp. 189-209.

Sánchez Salas, D. (2007) Historias de luz y papel: El cine español de los años veinte, a través de su adaptación de la narrativa española. Murcia: Murcia Cultural.

Sanders, J. (2006) Adaptation and Appropriation. London: Routledge.

Santaolalla, I. (2005) Los "otros": "Etnicidad y "raza” en el cine español. Zaragoza: Universidad de Zaragoza.

Smith, P. J. (2006a) Television in Spain: From Franco to Almodóvar. Woodbridge: Boydell and Brewer.

Smith, P. J. (2006b) Spanish Visual Culture: Cinema, Television, Internet. Manchester: Manchester University Press.

Smith, P. J. (2009a) Spanish Screen Fiction: Between Cinema and Television. Liverpool: Liverpool University Press.

Smith, P. J. (2009b) Media Migration and Cultural Proximity: Television Fiction in Spain. Studies in Hispanic Cinemas 5 (1-2): 73-84.

Stam, R. (2005) Introduction: The theory and practice of adaptation. In: Stam, R. and Raengo, A. (eds.) Literature and Film: A Guide to the Theory and Practice of Film Adaptation. Oxford: Blackwell, pp. 1-52.

Thompson, K. (2003) Storytelling in Film and Television. Cambridge, MA: Harvard University Press. 
Torres, R. (1997) Pilar Miró: "Lope se adelanta a su tiempo en los personajes femeninos." El País (March 5). Online at: http://elpais.com/diario/1997/05/03/cultura/862610407_ 850215.html (accessed May 22, 2010).

Vega, L. de (1991) El perro del hortelano. Madrid: Espasa Calpe.

Vilches, L. (2007) Culturas y mercados de la ficción televisiva en Iberoamérica. Barcelona: Gedisa. Vincendeau, G. (2001) Introduction. In: Vincendeau, G. (ed.) Film/Literature/Heritage: A Sight and Sound Reader. London: BFI, pp. xi-xxxi.

Williams, R. (1990) Television: Technology and Cultural Form. London: Routledge.

\section{Further Reading}

Deveny. T. G. (1999) Contemporary Spanish Film from Fiction. Lanham: Scarecrow Press.

Diego, P. (2010) La ficción de la pequeña pantalla: Cincuenta años de series en España. Pamplona: Universidad de Navarra.

Martínez-Carazo, C. (2008) Novela española y cine a partir de 1939. Online at: http:// descargas.cervantesvirtual.com/servlet/SirveObras/nec/34692843210125086521457/ 029293.pdf ?incr=1 (accessed May 23, 2010).

Martin-Márquez, S. (2009) Spanish Literature and the Language of New Media. In: Gies, D. T. (ed.) The Cambridge History of Spanish Literature. Cambridge: Cambridge University Press, pp. 739-55.

Mínguez Arranz, N. (1988) La novela y el cine: Análisis comparado de los discursos narratives. Valencia: Ediciones de la mirada.

Román, M. (1994) Memorias de la copla. La canción española: De Conchita Piquer a Isabel Pantoja. Madrid: Alianza.

Sánchez Noriega, J. L. (2000) De la literatura al cine: Teoría y análisis de la adaptación. Barcelona: Paidós.

Vegas López-Manzanares, F. (2003) La arquitectura de la Exposición Regional Valenciana de 1909 y de la Exposición Nacional de 1910. Valencia: Biblioteca TC. 


\section{Contents}

Acknowledgments viii

List of Figures $\quad$ ix

List of Contributors xviii

1 Introduction 1

Jo Labanyi and Tatjana Pavlović

$\begin{array}{lll}\text { Part I Reframing the National } & 13\end{array}$

2 Transnational Frameworks $\quad 15$

Gerard Dapena, Marvin D'Lugo, and Alberto Elena

Brad Epps

4 Negotiating the Local and the Global: Andalusia,

the Basque Country, and Galicia

José Colmeiro and Joseba Gabilondo

Part II The Construction of the Auteur

5 Auteurism and the Construction of the Canon 113 Marvin D'Lugo and Paul Julian Smith

6 Strategic Auteurism Antonio Lázaro-Reboll, Steven Marsh, Susan Martin-Márquez, and Santos Zunzunegui 
Part III Genre

7 Comedy and Musicals

Steven Marsh, Chris Perriam, Eva Woods Peiró, and Santos Zunzunegui

8 Melodrama and Historical Film

Jo Labanyi, Annabel Martín, and Vicente Rodríguez Ortega

Jo Labanyi, Antonio Lazaro-Reboll, and Vicente Rodriguez Ortega

\section{Part IV Stars as Cultural Icons}

10 The Construction of the Star System

Kathleen M. Vernon and Eva Woods Peiró

11 Stars, Modernity, and Celebrity Culture

Tatjana Pavlovic, Chris Perriam, and Nuria Triana Toribio

\section{Part V Image and Sound}

12 Photography, Production Design, and Editing

Vicente Sánchez-Biosca

13 Soundtrack

Romain Gubern and Kathleen M. Vernon

Part VI The Film Apparatus: Production, Infrastructure, and Audiences

14 Censorship, Film Studios, and Production Companies Josetxo Cerdán, Román Gubern, Jo Labanyi, Steven Marsh, Tatjana Pavlovic, and Nuria Triana Toribio

15 Film Clubs, Festivals, Archives, and Magazines Ferran Alberich, Román Gubern, and Vicente Sánchez-Biosca

16 Audiences Manuel Palacio and Kathleen M. Vernon

Part VII Relations with Other Media

17 Cinema, Popular Entertainment, Literature, and Television 
Part VIII Beyond the Fiction Film

18 Newsreels, Documentary, Experimental Film, Shorts, and Animation

Josetxo Cerdan and Vicente Sánchez-Biosca

\section{Part IX Reading Films through Theory}

19 Isabel Coixet's Engagement with Feminist Film Theory:

From $\mathrm{G}$ (the Gaze) to $\mathrm{H}$ (the Haptic)

Susan Martin-Márquez

20 Becoming a Queer (M)Other in/and/through Film:

Transsexuality, Trans-subjectivity, and Maternal

Relationality in Almodóvar's Todo sobre mi madre

Julian Daniel Gutiérrez-Albilla

21 The Space of the Vampire: Materiality and Disappearance in the Films of Iván Zulueta

Brad Epps

Index 